for when we got to the Monkey House, a young chimpanzec jumped into his arms and giggled with delight on seeing him. Chairs were brought and Toby continued to nurse and tickle that youngster who showed clearly how devoted he was to Toby.

When we got to the Tiger House I got a surprise for there I was admiring a grand specimen of a full grown tiger, when the keeper told me he was quite tame and went by the name of "Charlie". After a few questions I asked to see the Head Keeper and found that the tiger had been sent by a planter in Coimbatore called Charlie Morris without a word as to how he had been tamed by the wonderful loving kindness of that young Sholiga.

\title{
I.U.P.N. SECOND GENERAL ASSEMBLY
}

\section{From Notes given by Dr. G. F. Herbert Smiti}

The second session of the Gencral Assembly of the International Union for the Protection of Nature was held in the Institut de Sociologie, Leopold Park, Brussels, from 18th to 23rd October, 1950, the first having been held two years previously at Fontainebleau, immediately after the establishment of I.U.P.N. The United Kingdom was represented by Dr. G. F. Herbert Smith (Leader), Miss P. Barclay-Smith, Dr. John Berry, Captain Keith Caldwell, Mr. A. B. Duncan, Dr. F. C. Fraser, and Dr. J. Ramsbottom. Thirty-four countries and twelve international organizations were represented. The President and Secretary-General were Dr. Ch. J. Bernard and Mr. J. P. Harroy who hold corresponding offices in the Union.

The opening day saw the appointment of Nominations and Finance Committees and the transaction of routine business. The Secretary-General reported on the first two years' activities. Miss E. Sam representing UNESCO described the work done since the Technical Conference at Lake Success in 1949, dealing particularly with the educational side and the fostering of youth movements for nature conservation. Thirty-six bodies were admitted to membership of the Union.

On the second day various countries reported on nature conservation and it was decided to allow institutions and societies in Germany and Japan to become members. Technical discussions took place on the third day. An Education Section is to be opened at Washington. A questionnaire is to be issued to clarify the meaning of such terms as "national park" and "nature reserve" and their use in various countries. On the Saturday morning the accounts and the budget for 1951 were 
approved. Dr. Herbert Smith was elected to fill the vacant Vice-Presidency created by the death of Mr. H. G. Maurice. The invitation of the Venezuelan Government to hold the Third Session at Caracas in $\mathbf{1 9 5 2}$ was accepted.

\section{THE SOCIETY'S BUSINESS}

A letter has been received from Sir Ulick Alexander, Keeper of the Privy Purse, informing the President that His Majesty has been graciously pleased to grant his Patronage to The Fauna Preservation Society.

His Majesty's Patronage had been previously granted to our Society under its old name of The Society for the Preservation of the Fauna of the Empire.

A suitable letter of thanks has been sent.

Presidency of the Society. - At a General Meeting held on 22nd February, 1951, the Marquess of Willingdon was unanimously elected President of the Society.

Meeting.-A General Meeting was held on 1st November, 1950, at which about thirty members of the London Appreciation Society were guests. After the President had spoken about the objects and work of our Society, two films on wild life in Canada and the U.S.A. were shown-" Life on the Western Marshes" and "High over the Border".

One Meeting of the Council and one each of the Finance and General Purposes Committee and the Publicity Committee have been held since the last issue of Oryx in October, 1950. A summary of the points of interest to members generally is given below :-

Fauna Preservation Film.--It was decided to proceed with the collection of a library of fauna films. The first of the series "The African Elephant" is in process of construction; it is being made from a film presented by Sir Geoffrey de Havilland.

Other wild life photographers have sent films and it is hoped that a series worthy of the Society can be built up.

Festival of Britain.--His Grace The Duke of Bedford having been so good as to agree to open the grounds of Woburn Park for a Fauna Preservation Society's Week from 28th May to 2nd June, 1951, the proposal was approved in principal.

(Further details will be found in "Editorial Notes".)

Teas at General Meetings.-The Council has decided that a charge of one shilling, being the actual cost, shall be made for cach tea served. 